
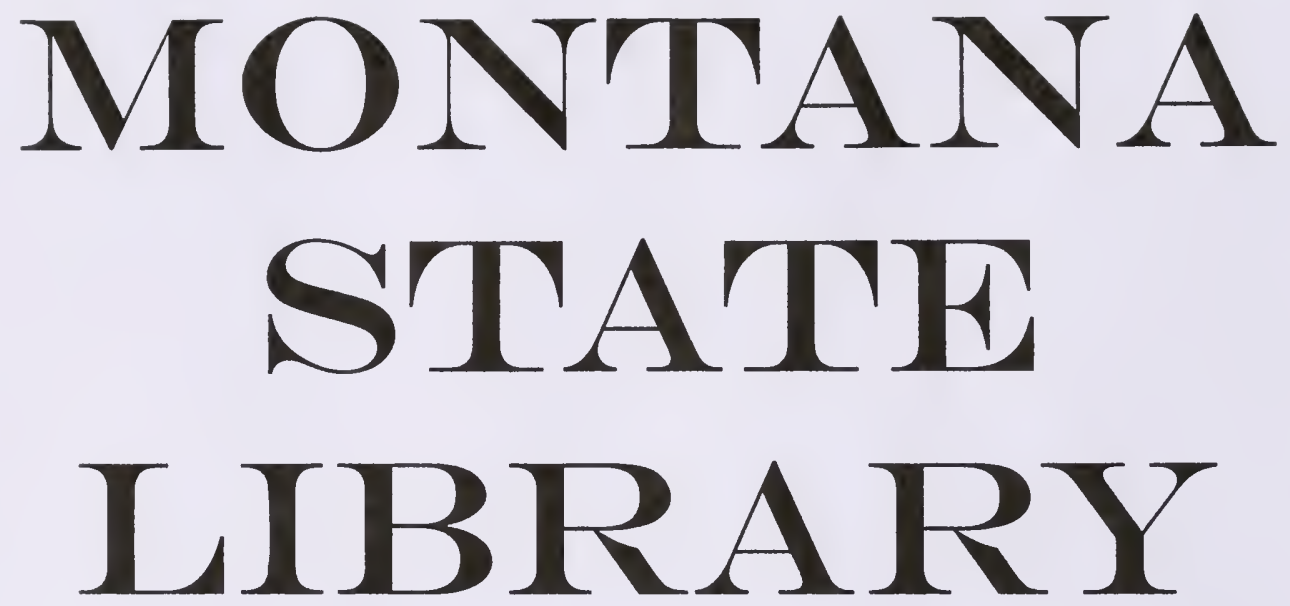

This "cover" page added by the Internet Archive for formatting purposes 


\section{REPORT ON THE CONSERVATION STATUS OF}

Erigeron lackschewitzii, A CANDIDATE THREATENED SPECIES

Taxon Name:

Common Name:

Family:

8tates Mhere Taxon Occurs:

Current Pederal status:

Recommended Federal status:

Author of Report:

Original Date of Report:

Date of Most Recent Revision:

Individual to Whom Further

Information and comments

should be sent:
Erigeron lackschewitzii Nesom and Weber

Front Mountain Fleabane

Asteraceae

Montana

USFWS Notice of Review, Category 2

USFWS Notice of Review, Category 2 barring taxonomic revision

Bonnie L. Heidel

March 1993

$N / A$

Bonnie L. Heidel

Montana Natural Heritage Program State Library Building

1515 E. 6th Avenue

Helena, MT 59620






\section{๑)1993 Montana Natural Heritage Program}

This document should be cited as follows:

Heidel, B. L. 1993. Report on the conservation status of Erigeron lackschewitzii, a candidate threatened species. Montana Natural Heritage Program. Helena, MT. 57 pp. 


\section{This is an abridged report}

For the full report please contact:

The Montana Natural Heritage Program

1515 E Sixth Ave

Helena, Montana 59620

406-444-3009 
I. SPECIES INFORMATION

1. Classification and nomenclature . . . . . . . . . . 1

2. Present legal or other formal status. . . . . . . . . 3

3. Description . . . . . . . . . . . . . . . 4

4. Significance. . . . . . . . . . . . . . . . 6

5. Geographical distribution . . . . . . . . . . . . 7

6. General environment and habitat description . . . . . Il

7. Population biology of the taxon . . . . . . . . . 15

8. Population ecology of the taxon . . . . . . . . . . 18

9. Current land ownership and management responsibility.19

10. Management practices and experience . . . . . . . . .20

11. Evidence of threats to survival . . . . . . . . . . 21

II. ASSESSMENT AND RECOMMENDATIONS

12. General assessment of vigor, trends, and status . . .21

13. Recommendations for listing or status change. . . . . 21

14. Recommended critical habitat. . . . . . . . . . . .22

15. Conservation/recovery recommendations . . . . . . . . 22

16. Interested parties. . . . . . . . . . . . . . . . 22

III. INFORMATION SOURCES

17. Sources of information. . . . . . . . . . . . . . 24

18. Summary of materials on file. . . . . . . . . . . . 24

IV. AUTHORSHIP

19. Initial authorship. . . . . . . . . . . . . 25

20. Maintenance of status report. . . . . . . . . . . . . . 25

V. NEW INFORMATION

21. Record of revisions

Literature Cited . . . . . . . . . . . . . . 26

Appendix A . . . . . . . . . . . . . . . . . . . 27

Appendix B . . . . . . . . . . . . . . . . . . . . . . . . . . .

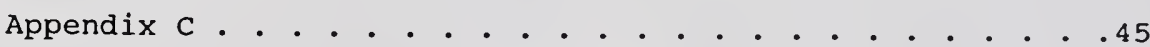

Appendix D . . . . . . . . . . . . . . . . . . . . . . . . . . . 
1. Classification and nomenclature.

A. Species.

1. Scientific name.

a. Binomial: Erigeron lackschewitzii Nesom and Weber

b. Full bibliographic citation: Nesom, G. L. and $W$. A. Weber. 1983. A new woollyheaded, monocephalous Erigeron

(Asteraceae) from Montana. Madrono 30 (4) :245-249.

c. Type specimens: Lackschewitz, K. H. 9101, 26 July 1979, USA, Montana, Flathead Co., Flathead Range, "North Wall" of continental divide, summit of mountain above Sock Lake. (Holotype: MONTU!; isotype: (CLO!).

Lackschewitz, K. H. 8487 , 29 July 1978, USA, Montana, Teton. Co., Flathead Range, summit of Headquarters Pass. (Paratype: COLO, MONTU, NY).

2. Pertinent synonyns: Treated as synonymous with Erigeron ochroleucus in Dorn (1984).

3. Common name: Front Range fleabane.

4. Taxon codes: PDAST3M4Fo (Montana Natural Heritage Program); 8234 ERILAC (U. S. Forest Service, Region 1).

5. 81ze of genus: The Erigeron genus contains nearly 200 species, growing in temperate or boreal latitudes of North and South America, Europe and Asia, as well as mountainous areas of tropical America.

B. Family olassification.

1. Pamily name: Asteraceae.

2. Pertinent family synonym: Compositae.

3. Common names for the family: Aster Family, Sunflower Family. 
c. Major plant group: Dicotyledoneae.

D. History of knowledge of taxon: The earliest known specimen is a recent collection (Lackschewitz 8487 29 July 1978, at the summit of Headquarters Pass, in the Flathead Range), deposited at the University of Colorado, University of Montana, and New York Botanical Gardens, representing the paratype collection. The type and paratype collections together represent a total of 18 plants, upon which the description is based. The species was named for its discoverer, Klaus Lackschewitz.

E. Comments on current alternative taxonomic treatments: Primary taxonomic references for the Erigeron genus of the Pacific Northwest region (Hitchcock and Cronquist 1984) and of the country (Spongberg 1971) preceded description of Erigeron lackschewitzii. Dorn (1984) treated it as a synonym of E. ochroleucus, Nesom (1989, and pers. commun. to Kerstetter) has made a revision of his treatment which makes Erigeron lackschewitzil synonymous with E. ochroleucus.

Taxonomic research is being pursued as part of this status review, conducted by Tul11 Kerstetter at Montana state University. A progress report of this work is submitted separately (Kerstetter 1993) and will be completed in 1994. The distinction between $\underline{E}$. lackschewitzii and other related species may warrant differentiation at the variety level (Kerstetter pers. commun.). The published distinctions do not seem adequate in themselves for differentiating E. lackschewitzij. The study underway will review morphological distinctions, as well as:

- chloroplast DNA

- chromosome number

- isozyme analysis

Erigeron lackschewitzii material keys out to E. ochroleucus in the floristic references mentioned above. Other related taxa being studied include E. radicatus, E. simplex, and tentatively $\underline{\text {. }}$ grandiflorus.

A complete summary of Erigeron lackschewitzii taxonomic standing will be prepared in 1994 as an update to this report. 
2. Present legal or other formal status.
A. International: None.
B. National.

1. United states.

a. Present designated or proposed legal protection or regulation: U. S. Fish and Wildife Service: Currently, the species is included in Category 2 of the U.S. Fish and Wildlife Service Notice of Review (U.S. Department of Interior 1990), under consideration for federal listing as a threatened or endangered plant species. Category 2 taxa are those "... for which information now in possession of the Service indicates that proposing to list them as endangered or threatened species is possibly appropriate, but for which substantial data on biological vulnerability and threat(s) are not currently known or on file to support the immediate preparation of rules." see $I . E$. regarding the taxonomic contingency to proposing listing.

b. Other current formal status:

Erigeron lackschewitzii was on the first Region 1 Sensitive Plant list of the U.S. Forest Service as "Watch" based on its presence in two national forests and Iimited distribution, though without recognized threats (USDA 1988). The Watch criteria were redefined in the 1991 list revision, such that watch species with low degrees of threat were excluded from consideration, including E. lackschewitzii (Lesica and Shelly 1991b). It is being tracked by the Lewis and Clark National Forest as a national forest species of concern because it is endemic, though it has no formal designation. The species is currently ranked as "threatened throughout its range, but having taxonomic questions a associated with it" (Nature conservancy global rank $=G 2 Q$ as assigned by the Montana Natural Heritage Program; Lesica and shelly 1991a). This rank has no legal status. 
2. State.

a. Montana.

i. present designated or proposed legal protection or regulation: None.

ii. Other current formal status recommendations: Erigeron lackschewitzii is currently ranked by the Montana Natural Heritage Program as "imperiled" at both global and state levels (global rank = G2; state rank = s2). These ranks do not provide any legal protection for $\underline{E}$. lackschewitzii.

\section{iii. Review of past status:} Previously listed as "rare in Montana" by the Montana Rare plant project (Lesica et al. 1984).

3. Description.

A. General nontechnical description: Small herbaceous perennial with unbranched stems, most often solitary but also in clusters; arising from a long, woody taproot and often from secondary and tertiary branches above the taproot. Involucre conspicuously woolly, obscuring bracts of live plants but loosing this character when pressed. Ray flowers bluish pink, drying light brown or purple when pressed; rays consistently oblique to the plane of the disk. stem leaves usually extending fully halfway up stem. stem moderately covered by a combination of long ascending to spreading hairs and short appressed hairs (latter not mentioned by Nesom and Weber 1983). Phyllaries appear deeply reddish-purple tipped when pressed (Kerstetter pers. obs., Heidel pers. obs.). See Appendix A for photos.

B. Technical description: Perennial herbs from a long, woody taproot with few or no branch or adventitious roots; caudex simple or with a few short (up to 2.5 $\mathrm{cm}$ long), thick branches to which old petiole bases may remain attached, each branch producing $1-5$ stems. Stems $3.5-8 \mathrm{~cm}$ high, more or less ascending, unbranched, lanate-villous flattened and twisted trichomes, more sparsely pubescent near the base. 
Basal leaves 1 inear-oblanceolate to narrowly oblanceolate, 20-60 mm long, 1.2-3 $\mathrm{mm}$ wide, gradually narrowed to a petiolar region. Margins entire, cauline leaves 5-10 and similar to the basal leaves, slightly reduced upwards or not, extending fully halfway up the stem; leaves densely to sparsely pubescent with a mixture of spreading and appressed or ascending trichomes up to $3 \mathrm{~mm}$ long, long-ciliate near the petiole base. Heads solitary; involucres shallowly hemispheric, $12-17 \mathrm{~mm}$ wide (pressed), 6-8 mm high; phyllaries in ca. 3 equal series, herbaceous, green, often with a golden midvein, narrowly lanceolate with acuminate, loose or reflexed tips, $0.5-1 \mathrm{~mm}$ wide, 5-8 $\mathrm{mm}$ long, densely white-villous, the trichomes usually with blackish-purple crosswalls, at least near the base. Ray flowers fertile, $30-68$ in $1(-2)$ series, apparently somewhat erect, $7.8-11.3 \mathrm{~mm}$ long, the tubular portion $1.8-2.5 \mathrm{~mm}$ long, conspicuously pubescent with both seriate and long uniseriate trichomes, ligules narrowly obovate, $1.6-3 \mathrm{~mm}$ wide, not reflexing or curling, drying light lilac to purple, 4-7 veined, the margins slightly inrolling, apex with $2-3$ shallow to deep notches; style branches $0.8-1.1 \mathrm{~mm}$ long, partially included within the tube. Disk corollas yellow, tubular, slightly indurated, pubescent, lobes $0.6-0.9 \mathrm{~mm}$ long, erect; anther $0.7-1 \mathrm{~mm}$ long, with lanceolate apical appendages, style branches $0.7-1 \mathrm{~mm}$ long, including the deltate to shallowly triangular collecting appendages. Achenes oblong-obovate, radially compressed, tan, with 2 thin ribs, strigose with long, untwisted, duplex trichomes; carpodium of 5-7 rows of cuboidal cells with a lower, inner row of subsidiary cells' pappus of ray and disc flowers similar, of 15-24 relatively thick but extremely brittle bristles, ca. $3 / 4$ as high as the disc corollas but somewhat uneven (from Nesom and Weber 1983).

c. Local field characters: E. lackschewitzii differs from E. Simplex in having basal leaves which are not spathulate and well-demarcated but are instead inear-oblanceolate to narrowly oblanceolate, and having only 30-68 ray flowers instead of 50-125. It also lacks conspicuously glandular trichomes (from Nesom and Weber 1983). In addition, E. simplex comes from a rhizhome which is usually horizontal, while E. lackschewitzii is taprooted, and it is found in more protected sites than E. lackschewitzii (Kerstetter pers. commun.). 
E. lackschewitzii is not compared with E. ochroleucus in the published literature but would be distinguished in the Hitchcock and cronquist key in having multicellular hairs on the involucre, i.e. a trichome with crosswalls. Examination of $\underline{E}$. ochroleucus specimens indicates presence of crosswalls, contradicting the keys (Kerstetter pers. commun., Lesica pers. commun.).

Similarly, both have basal leaves which are linear and with an enlarged membranous base, contradicting the keys.

E. lackschewitzii is consistently pinkish blue, while E. ochroleucus ranges in color from bluish purple to pink and to white. Likewise, the disk corolla length and the involucre bract length are usually different, with the dimensions of the E. lackschewitzii feature circumscribed in the wider range of $\underline{E}$. ochroleucus features (Kerstetter pers. commun.). See Appendix A for a photograph of the two species growing side by side.

E. lackschewitzii is distinguished from

E. radicatus in having cauline leaves, larger disk corolla $(2.8-4.3$ vs. $2.3-3.0)$ and more pappus bristles (10-20 vs. 6-12); (from Hitchcock and cronquist key)

D. Identifying characteristics of material which is in interstate or international commerce or trade: None.

E. Photographs and Iine drawings: Appendix A provides a copy of the technical illustration of Erigeron lackschewitzii, along with close-ups and habitat photographs.

4. Bignificance.

A. Natural: The community and landscape role of Erigeron lackschewitzii warrants investigation. circumstantial evidence in its morphology and distribution pattern indicate that it may be uniquely suited to the alpine "wind community".

B. Human: Erigeron lackschewitzil is among the few endemic alpine species in Montana, its narrow distribution and habitat overlapping with that of another endemic, Cardamine rupicola. Erigeron lackschewitzii has fidelity to a narrow range of 
harsh alpine conditions and is a study in species adaptation. Other limestone substrate endemics in Montana are species of lower elevations. These species and their communities are subject for extended phytogeographic study as initiated by Bamberg and Major (1968). It has no known horticultural or economic uses at this time.

\section{Geographical distribution.}

A. Geographical range: Erigeron lackschewitzii is currently known from a total of 12 sites in four counties of Montana (Teton, Flathead, Pondera and Lewis and clark). Sites lie within ca. 45 miles north-south along the Front Range. Most sites have been documented east of the continental Divide, but at least one site is located west of the Divide in the Bob Marshall Wilderness. The range is depicted in Appendix D.

Potential habitat was identified in this study using the map of surface geology having the greatest detail (Mudge and Earhart 1977), focusing upon the Madison Group and Devonian formations containing dolomite. These formations are the prevalent surface geology from the easternmost edge of the Front Range westward to within a few miles of the Sun River (ca. 10 miles east-west; the majority outside of Bob Marshall Wilderness boundaries). Their presence further west is limited, and part is at lower elevation which are forested.

B. Precise occurrences.

1. Populations currently known to be extant.

Occurrence number 001 Survey site: MOUNT HRIGHT

County: Teton

Latitude: $475833 \mathrm{~N}$ Longitude: 1124959 $\mathrm{W}$ Elevation: 7500 USGS quadrangle: MOUNT HRZIGHT

Township/range: Section: 026N010W 25

Additional/quarter sections: S2; 26 SE4

Initial discovery: 1982 Most recent observation: 1992-07-17

Directions: EAST FLANK OF MOUNT HRIGHT, EAST FRONT RANGE; NORTH OF IRAIL IN SADDLE.

Occurrence number: 002 Survey site: HEADQUARTERS CREEK PASS/ROCKY MOUNTAIN

County: Teton

Latitude: $474915 \mathrm{~N}$ Longitude: $1124822 \mathrm{~W}$ Elevation: 7760 USGS quadrangle: OUR LAKE 


\begin{abstract}
$\begin{array}{lll}\text { Township/range: } & \text { Section: Additional/quarter sections: } \\ \text { 024N009N } & 19 & \text { E2; } 30 \text { NE4 }\end{array}$
Initisl discovery: 1978 Most recent observation: 1989-08-10

Directions: ROCKY MOUNTAIN FRONT RANGE, HENDOUARTERS CREEK PASS AND WEST SLOPE OF ROCKY HOUNTAIN.
\end{abstract}

Occurrence number: 003

Survey site: SOCK LAKE

County: Lewis and Clark, Flathead

Latitude: 474740N Longltude: 1130352N Elevation: 8200

USGS quadrangle: THREE SISTERS

Tounship/range: Section: Additional/quarter sections: 024N011W 31 NE4

Initial discovery: 1979 Most recent observatton: 1979-07-26

Directlons: FLATHEAD RANGE, "M WALL" OF CONTINENTAL DIVIDE, SUMAIT OF MOUHTAIN ABOVE SOCK LAKE.

Dcarrence number: 006

Survey site: CORRUGATE RIDGE

County: Teton, flathead

Latltude: 480068N Longltude: 1125340 Elevation: 8000

USGS quadrangle: GATEWAY PASS

Tounshlp/range: Section: 026 W010 16

Additional/quarter sections: 9

Inltiol discovery: 1983

Most recent observation: 1983-07-29

Directlons: CORRUGATE RIDGE, ALONG CONTINENTAL DIVIDE ABOVE WEST SIDE OF HENDWATERS OF BRUCE CREEK.

Dcaurrence nuber: 005

SUrVey site: MONT PATRICK GASS

County: Teton

Latitude: $480109 \mathrm{~N}$ Longitude: $1125230 \mathrm{~W}$ Elevation: 7800

USGS quadrangle: WALLING REEF

GATEuAY PASS

Towship/range: Section: 026+1010

10

Additional/quarter sections: N2; 15 NE4

Initial discovery: 1983

Most recent observstion: 1983-07

Directions: SOUTH FLANKS OF MOUNT PATRICK GASS, ON DIVIDE BETWEEN BRUCE CREEX AHD CRAZY CREEK.

Ocarrence number: 006

Survey site: CRON MOUNTAIM

County: Lewis and Clark

Latitude: 472224 L Longitude: $1124535 \mathrm{~W}$ Elevation: 7200

USCS quadrangle: SCAPEGOAT HOUNTAIN

Tounship/range: Section: Additional/quarter sections:

019 N009N 28 NH4; 29 MEG

Inftial discovery: 1986 Most recent observation: 1992-07-23

Directions: FRONT RANGE MOUNTAINS, SOUTH-FACING SLOPES OF CROWN MOUNTAIK WEST OF THE PASS, ACROSS FROM PACK TRAIL. 
Occurrence nuber: 007

Survey site: QUR LAKE

County: Teton

Latitude: 474947N Longitude: 1124840 Elevation: 8400

USGS quadrangle: OUR LAKE

Township/range: Section: Additional/quarter sections:

024HOOSW 18 WR

Initial discovery: 1986 Most recent observation: 1992-07-24

Directions: fRONT RAMGE MOUNTAINS, CA. 25 MILES VEST OF CHOTEAU, ABOVE QUR LAKE ON RIDGE HORTH OF HEADOUARTERS PASS AND ON SADDLE SLOPES WEST OF OUR LAKE.

Occurrence nuber: 008

Survey site: TETON SKI AREA PEAK

County: Teton

Latitude: $4 \pi 554 \mathrm{~N}$ Longltude: 1124955 $\mathrm{W}$ Elevation: 7960

USGS quadrangle: MOUNT WRIGHT

Tounship/range: Section: Additionol/quarter sections:

025N010W 12 SE4

Initial discovery: 1989 Nost recent observation: 1989-08-08

Directions: CA. 34 MILES UEST OF CHOTEAU, ON UEST SIDE OF PEAK ABOVE TETON PASS SKI AREA.

Ocarrence numer: 009

Survey site: WASHBOARD REEF

County: Teton

Latitude: 475601 $\mathrm{H}$ Longitude: 1125313W Elevation: 7920

USGS quadrangle: PORPHYRY REEF

Tounship/range: Section: Additionsl/quarter sections:
025H010N

Initlal discovery: 1992-07-25 Most recent observation: 1992-07-25

Directions: MORTH OF TRAIL 117 ON WASHBOARD REEF RIDGELINE; OVER 6 MILES FROM WEST FORK TETON TRAILHEND.

Ocarrence nutber: 010

Survey site: SHIFT RIVER

County: Pondera

Latitude: 480838N Longitude: 1125112W Elevation: 6400

USGS quadrangle: FISH LAKE

Township/range: Section: Additional/quarter sections: 028N010 35 H2NEG

Initial discovery: 1992-07-26 Most recent observation: 1992-07-27

Directions: ABOVE SWIFT RIVER RESERVOIR, 1.25 MILES SOUTHEAST OF ONH ON RIDGE AT EAST EDGE OF FRONT RANGE.

Occurrence number: 011

Survey site: VOLCAMO REEF

County: Teton

Latitude: 480116N Longitude: 1124315W Elevation: 6740

USGS quadrangle: VOLCANO REEF 
Occurrence ruber: 011 (cont.)

Tounship/range: Section: Additional/quarter sections:



Initial discovery: 1992-07-27 Kost recent observation: 1992-07-27

Directions: VOLCANO REEF RIDGETOP AT EAST EDGE OF FRONT RAMGE, NORTH OF BLACKLEAF CAMYON.

Ocaurrence nuber: 012

SUrvey site: STEAMBOAT LOOKOUT

County: Lewis and Clark

Latitude: $471834 \mathrm{~N}$ Longitude: $1123851 \mathrm{~W}$ Elevation: 8280

USCS quadrangle: JAKIE CREEK

Tounship/range: Section: Additional/quarter sections:

018N008W $\quad 17 \quad 52$

Initial discovery: 1992-07-28 Most recent abservation: 1992-07-28

Directions: LOER EAST END OF RIDGE DIRECTLY NORTH OF STENIBOAT MOUNTAIN

LOOKOUT, NORTH OF UWHUMBERE IRAIL TO LOOKOUT; OVER 6 MILES

ABOVE TRAILHEND ON ELK CREEK.

2. Populations known or assumed extirpated.

a. Montana: N/A

3. Historioally known populations where current status 18 not known:

a. Montana: N/A

1. Locations not yet investigated believed likely to support aditional natural populations:

There is little or no further dolomite substrate farther east or south of known populations. Potential habitat extends northward into Badger-Two Medicine area stopping before Glacier National Park. potential habitat which has not been investigated extends intermittently westward into Flathead National Forest within Bob Marshall Wilderness Area, though the largest area of potential habitat is within Lewis and clark National Forest.

5. Reports having ambiguous or incomplete locality information:

a. Montana: N/A 

6. Locations known or suspected to be erroneous reports:

\section{a. Montana: $\mathbf{N} / \mathbf{A}$}

c. Biogeographical and phylogenetic history:

contingent on taxonomic research underway

6. General environment and habitat description.

A. Concise statement of general environment and

habitat: Erigeron lackschewitzii is a terrestrial plant which grows primarily in exposed alpine settings on calcareous soil derived from dolomite. It typically grows in association with intermittent mats of Dryas octopetala and as well as

Artostaphylos uva-ursi. Carex rupestris is the dominant sedge between mats. In its driest habitat settings, E. lackschewitzii grows on barren slopes with only trace amounts of the associated species. At the moistest habitat settings, it grows in carex rupestris turf with high forb diversity.

B. Physical characteristics.

1. Climate.

a. Koppen climate classification: Type Dfb (cool temperate climate, with numerous summer thunderstorms), the climate type of the Rocky Mountains (Visher 1954).

b. Regional macroclimate: The climate of the Front Range is typical of alpine settings in the short 30-50 day growing season (duration of frost-free days), and high mean annual precipitation of 40-60 inches. It differs from most other mountainous areas of the state in having a late time in the season during which soil recharge begins, July 20-August 8 ; coinciding with the flowering period of $\underline{E}$. lackschewitzii (from Caprio and Nielsen 1992).

c. Local microclimate: Quantitative data is not available on microclimate, but it seems to represent wiridy settings with high evapotranspiration, and relatively exposed sites which would be among the earliest to melt free of snow. 
2. Air and water quality requirements: N/A

3. Physiographic province: Northern Rocky Mountains (Fenneman 1931)

4. Physiographic and topographic characteristics: Erigeron lackschewitzii was most frequently found on exposed alpine slopes having southwest aspect. Many of the sites are at or near topographic features which break wind velocity, including saddles, protruding outcrops, and crests of updraft chutes. The majority of sites lie along a single divide between the sun River and Teton River drainages.

It grows on midslope settings often between scree and toeslope turf, or on gentle but highly exposed slope crests and ridgelines. This microtopography is limited within the Front Range, and was wanting at the sites of unsuccessful searches conducted in the course of this project.

In addition to the typical settings of the large, south-facing alpine population sites, there are also small northwest-facing populations at both alpine and subalpine elevations. The elevations range from 64008200 feet, the low sites located in exposed settings at the east edge of the Front Range.

5. Edaphic factors: Erigeron lackschewitzii is found exclusively on calcareous soil derived from dolomite, the overriding factor circumscribing its potential habitat in the Front Range. Soils are cryptorthents of gravelly silt or loam, varing in their degree of organic matter and in their surface cover. Typical cover has almost $50 \%$ cobble and pebble rock fragments, though the range of rock cover ranges from 5-95\%. While these soils are relatively thin, water loss is impeded by surface rock cover, and water retention in limestone-derived soils is higher than that of soils from many other parent materials.

6. Dependence of this taxon on natural disturbance: There was no apparent correlation with alpine disturbance processes like solifluction and frost heaving. 
c. Biological characteristics.

1. Vegetation physiognomy and community structure: Most population sites fit the description of Bamberg's Dryas octopetala community, as studied northward at Siyeh Pass (1964). However, they had neither the continuous Dryas cover or sharp patterning described by Bamberg.

Dominance by Carex rupestris to the exclusion of shrubs was noted at some sites, a prevailing sedge community dominant as identified in Bamberg's work.

2. Regional vegetation types: Most sites fall within the Dryas octopetala / Carex spp. plant association, classified and ranked as G5S5 by the Montana Natural Heritage Program.

3. Frequently associated species: A composite list of associated species found at more than one site is listed as follows in approximate decreasing order of frequency.

Shrubs

Dryas octopetala

Arctostaphylos uva-ursi

Potentilla fruticosa

Graminoids

Carex rupestris

Poa alpina

Festuca rubra

Kobresia myosuroides

Trisetum spicatum

Forbs

Androsace chamejasme

Antennaria aromatica

oxytropis sericea

Erigeron compositus

Arenaria congesta

Smelowskia calycina

Eriogonum flavum

Erigeron ochroleucus

Astragalus molybdenus

Townsendia parryi

Sedum rosea

Bupleurum americanum

Senecio cana 
4. Dominance and frequency of the taxon: Erigeron lackschewitzii generally occurs as a rare, uncommon, or occasional species in its plant communities, but was noted as "common" at its largest population site. It is not among the community dominants.

5. Successional phenomena: Bamberg (1964) proposed that Dryas mats lead successionally to sedge meadow turf. If Dryas cover and sedge cover are indicative of succssional status, then Erigeron lackschewitzii is present over a wide range of successional stages. Dryas species fix nitrogen, indicative of the successional role in building soil fertility.

The single site of E. lackschewitzii intermixerd with tree cover of pinus flexilis had been burned within recent years, killing the krummholtz tree growth over most of the burn slope. This is insufficient information for characterizing fire response of the species.

6. Dependence on dynamic aspects of biotic associations and ecosystem features: The exposed alpine habitat occupied by E. lackschewitzii has climate extremes within the growing season and this may reflect a relation with dynamic ecosystem features.

7. other endangered, threatened, rare, or vulnerable species occurring in habitat of this taxon: Erigeron lackschewitzii is on the same summits as six other plant species of state concern. It sometimes adjoins or overlaps habitat with the first of these, but is otherwise in different localized settings.

Astragalus molybdenus (G3S2)

Botrychium pradoxum, another category 2 species (GISI)

Cardamine rupicola, another Montana endemic (G3S3)

Carex maritima var. incurviformis (G2G3T?S1)

oxytropis podocarpa (G4SI) 
Saussurea densa (G3SI)

In addition, it grows in the same habitat as Antennaria aromatica, currently considered a Category 2 species (USDI 1990) though it is widespread in Montana.

7. Population biology of the taxon.

A. General summary: Populations of Erigeron lackschewitzii range in numbers from 5-500 individual plants, with the median being ca. 100. Populations at or above median size are usually concentrated in small areas of less than ten acres, while diffuse populations may be spread for over a mile.

B. Demography.

1. Rnown populations: Twelve (Note: two pairs of sites tallied as separate populations lie within 1 mile of one another; Corrugate Ridge and Mount Patric Gass, and our Lake and Headquarters Creek Pass)

2. General demographic details (Montana):

a. site (001) Mount Wright

1. Area occupied by population: 2

2. Estimated number of individuals: ca. 100

b. site (002) Headwaters Creek Pass

1. Area occupied by population: 10

2. Estimated number of individuals: 200-300

c. site (003) Sock Lake

1. Area occupied by population: 2

2. Estimated number of individuals: 500

d. site (004) Corrugate Ridge

1. Area occupied by population: 10

2. Estimated number of individuals: fewer than 200

e. site (005) Mount Patrick Gass

1. Area occupied by population: 20

2. Estimated number of individuals: $110-140$ 
f. site (006) Crown Mountain

1. Area occupled by population: 10

2. Estimated number of individuals:

$150-300$

g. site (007) our Lake

1. Area occupied by population: 10

2. Estimated number of individuals: 200-400

h. site (008) Teton Ski Area Peak

1. Area occupied by population: 1

2. Estimated number of individuals: "small"

i. site $(009)^{\circ}$ Washboard Reef

1. Area occupied by population: widely distributed along 1.2 mile of ridge

2. Estimated number of individuals: 8

j. site (010) swift River Reservior

1. Area occupled by population: 1

2. Estimated number of individuals: 5

k. site (011) Volcano Reef

1. Area occupied by population: widely distributed along 0.5 mile of ridge

2. Estimated number of individuals: 10

1. site (012) Steamboat Lookout

1. Area occupled by population: 5

2. Bstimated number of individuals: 150

c. Phenology.

1. Patterns: Collections have been made between July 17 to August 10, presumably from plants in flower. In 1992, plants had evidently been flowering before the date of the first field survey on July 17 in what was an early year. The mid-July flowering in 1992 may have been a week early.

Flowering is fairly synchronous throughout the range of settings and on individual plants, spanning less than three weeks except for a few sites having a small number of vigorous multistemmed plants that produce late flowers. 
2. Relation to climate and microclimate: Erigeron lackschewitzii blooms with other plants that do not initiate growth until after snowmelt. The exposed setting is not known to have a special role in its phenology.

D. Reproductive ecology.

1. Types of reproduction: None of the flower buds collected in 1992 had produced pollen (Kerstetter pers. obs.). This is taken as preliminary evidence of apomictic reproduction (Kerstetter pers. comun.).

2. Pollination.

a. Mechanisms: It is possible that fertilization takes place without pollination (see above). It is also interesting to note that the oblique angle of the ligule would seem like an impediment to pollinator visitation.

b. specific known pollinators: None known

c. other suspected pollinators: None known

d. Vulnerability of pollinators: None known

3. seed dispersal.

a. General mechanisms: Pappus bristles aid in wind dissemination

b. specific agents: None known

c. Vulnerability of dispersal agents and mechanisms: None known

d. Patterns of propagule dispersal: It has been noted that populations are established at points on the landscape where strong winds converge and eddy.

4. seed biology.

a. Amount and variation of seed production: seed production is expected to vary little among flowering plants, as judged by the uniformity of flowering stalk number and corolla disk diameter. It is assumed that disk corolla size reflects seed numbers. 
b. seed viability and longevity: viability has yet to be tested.

c. Dormancy requirements: Unknown. Probably hardened by freezing temperatures over winter.

d. Germination requirements: Unknown

e. Percent germination: Unknown

5. seedling ecology: Unknown

6. Survival and mortality: No data available; the species occurs most often in open habitat where the "safe site" spaces between loose rock would be more favorable for establishment than vegetation turf.

7. Overall assessment of taxon's reproductive success: It is hypothesized that reproduction does not vary by more than small factors from year to year, as indicated by the uniformity of flowering stalk numbers and disk corolla diameter in comparing specimens. Basal rosettes without infloresences were not noted, and this is an unknown life history component. Seedling establishment would be expected to vary greatly according to recruitment as affected by wind and rainfall patterns.

8. Population ecology of the taxon.

A. General summary: Erigeron lackschewitzii occupies areas of open vegetation, but can also persist if not establish in carex rupestris turf.

B. Positive and neutral interactions: Individuals of Erigeron lackschewitzii appear to be randomly distributed, except at the lowest population densities which have slightly clumped patterns. This is taken to signify neutral intraspecific interaction.

c. Negative interactions.

1. Herbivores, predators, pests, parasites and diseases: None observed

2. Competition. 
a. Intraspecific: None observed

b. Interspecific: It rarely becomes established within mats of Dryas octopetala or Arctostaphylos uva-ursi.

3. Toxic and allelopathic interactions: None observed

D. Hybridization.

1. Naturally occurring: Individuals of Erigeron lackschewitzii had the field features noted under previous description text. The absence of morphological intermediates despite the proximity of other Erigeron species is indication that hybridization is not occurring or is not frequent.

2. Artificially induced: Research in progress.

3. Potential in cultivation: Unknown

E. Other factors of population ecology: Research in progress on variability within and between populations as part of isozyme work.

9. Current land ownership and management responsibility.

A. General nature of ownership: All known populations are on public land.

B. Specific landowners (Montana): Ten of the twelve known populations are on Lewis and Clark National Forest, one is on Flathead National Forest (003), and one is on state school Land (010).

c. Management responsibility: The Lewis and clark National Forest Service populations are all within the Rocky Mountain District; the Flathead National Forest site is on the spotted Bear District.

D. Easements, conservation restrictions, etc.: The majority of sites are in or straddling divides marking the boundary of the Bob Marshall Wilderness Area and the Scapegoat Wilderness Area. They include the Flathead National Forest site, and eight Lewis and Clark National Forest sites. 
10. Management practices and experience.

A. Habitat management.

1. Review of past management and land use experiences: There has been little management activity in alpine terrain apart from construction of lookout towers.

2. Performance under changed conditions: No data available. It occupies a burn site above swift Reservior.

3. Current management policies and actions: Fire lookout towers have been taken out of operation near at least two populations, at Mount wright and steamboat Mountain. Repeater station installations have recently been proposed at both sites, but are not being pursued at this time (Phillips pers. commun.). Military mountaintop heliccopter landings are being proposed within ten miles of the latter on Helena National Forest, but are not being considered on the Lewis and Clark National Forest. There was not indication that the proximity of hiking and pack trails near the populations poses potential threats. Oil drilling work has taken place within a mile of the Volcano Reef site below the montane zone.

\section{Future land use: Unknown}

B. Cultivation.

1. Controlled propagation techniques: Unknown.

2. Ease of transplanting: Erigeron ochroleucus is a species of similar stature and size $t$ hat has been transplanted for rock gardening (Barr 1983) though it is not in horticultural trade. The tendency of E. lackschewitzii to keep a "closed" appearance may make it less desirable than other species of the genus for cultivation.

3. Pertinent horticultural knowledge: Unknown

4. Status and location of presently cultivated material.

a. Specimen plants: $\mathrm{N} / \mathrm{A}$ 
b. Belf-sustainging breeding populations: $\mathrm{N} / \mathrm{A}$

c. stored seed: Seed will be germinated at Montana State University in 1993.

11. Evidence of threats to survival.

A. Present or threatened destruction, modification, or curtailment of habitat or range: Unknown

B. Overutilization for commercial, sporting, scientific, or educational purposes: Collecting for research needs to be done with regard to potential impacts. It has been mainly limited to collection of flower buds and basal leaves to date.

C. Disease, predation, or grazing: None known

D. Inadequacy of existing regulatory mechanisms: None known

E. Other natural or man-made factors: None known

\section{ASSESSMENT AND RECOMMENDATION8}

12. General assessment of vigor, trends, and status:

Erigeron lackschewitzii is known from twelve populations totaling ca. 1800 individuals. At least three of these are interpreted to represent small waif populations that to not contribute to population viability. Trend information is not available. Status hinges on taxonomic questions.

13. Recommendations for listing or status change.

A. Recommendation to U.8. Fish and Fildlife service: Contingent on taxonomic research underway.

B. Recommendations to other U.8. federal agencies: Maintain interim information files on Erigeron lackschewitzii as a species whose viability potentially hinges on management actions of the U.S. Forest Service. Further review warranted pending taxonomic research.

c. Other status recommendations. None

1. Counties and local areas: N/A

2. states: $N / A$ 
14. Recommended critical habitat: Recommended critical habitat encompasses the largest populations having over 200 individuals, contigent on taxonomic research:

\#002 Headquarters creek Pass at T24N R9W Sec. 19 E $1 / 2$ and adjoining Sec. $30 \mathrm{NE} 1 / 4$

\#003 Sock Lake at T24N R11W Sec. $31 \mathrm{NE} 1.4$

\#006 Crown Mountain at T19N R9W Sec. 28 NW $1 / 4$ and adjoining Sec. $29 \mathrm{NE} 1 / 4$

\#007 Our Lake at T24N R9W Sec. $18 \mathrm{~W} 1 / 2$

15. Conservation/recovery recommendations. Taxonomic information is needed to address the following subjects, to be covered in 1994 update.

A. General conservation recommendations.

1. Recommendations regarding present or anticipated activities: See above

2. Areas recommended for protection: See above

3. Habitat management recommendations: See above

4. Publicity sensitivity: Low level of sensitivity at present

5. Other recommendations: None at this time

B. Monitoring activities and research needs: See above

16. Interested parties:

Office of Endangered Species

ATTN: Dr. James Miller

U.S. Fish and Wildlife Service

P.O. Box 25486

Denver Federal Center

Denver, CO 80225

U.S. Fish and Wildlife Service

ATTN: Dale Harms

Federal Building, 301 S. Park

P.O. Box 10023

Helena, MT 59626 
Office of Endangered Species

ATTN: Dr. John Fay

U.S. Fish and Wildlife Service

Washington, D.C. 20240

U.S. Forest Service, Region one ATTN: Steve Shelly

Federal Building

P.O. Box 7669

Missoula, MT 59807

Lewis and Clark National Forest

ATTN: Wayne Phillips

P.O. Box 871

Great Falls, MT 59423

Flathead National Forest

ATTN: Dave Bunnell

1935 Third Ave. East

Kalispell, MT 59901

Tulli Kerstetter

Department of Biology

Montana State University

Bozeman, MT 59771

Klaus Lackschewitz

6322 Woods Road

Missoula, MT 59802

Peter Lesica

Ecological Consulting

929 Locust

Missoula, MT 59802

The Nature Conservancy

ATTN: Dr. Larry Morse

1815 North Lynn street

Arlington, VA 22209

The Nature Conservancy

ATTN: Bernie Hall

Montana Field office

32 South Ewing

Helena, MT 59601

Montana Department of State Lands

1625 Eleventh Avenue

Helena, MT 59620-1601 
Montana Native Plant Society

P.O. Box 992

Bozeman, MT 59771

Montana Natural Heritage

State Library Building

1515 E. 6th Ave.

Helena, MT 59620

\section{INFORMATION SOURCES}

17. Sources of Information.

A. Publications.

1. References cited in report: See Literature Cited (pp, 26).

B. Museum collections: Voucher specimens collected in Montana during field work on this project are cited in the SPECIMEN field on the computer printouts (Appendix B) and are deposited at MONT, with duplicate material at MONTU. Previously collected specimens from Montana are cited in the SPECIMEN field as well.

c. Fieldwork.

1. Surveys conducted: B.L. Heidel 17 July, 23-28 July 1992 .

D. Knowledgeable individuals: See addressed under interested parties

Tulli Kerstetter

Klaus Lackschewitz

Peter Lesica

Wayne Phillips

Steve Shelly

E. Other information sources: Color slides of additional populations in Montana are on file at the Montana Natural Heritage Program office.

18. Summary of materials on file: All detailed field survey forms and field maps, and most references cited, are on file at the Montana Natural Heritage Program office. 
IV. AUTHORSHIP

19. Initial authorship:

Bonnie L. Heidel

state Library

Montana Natural Heritage Program

1515 East 6th Avenue

Helena, MT 59620

(406) 444-3009

20. Maintenance of status report: The Montana Natural Heritage Program will maintain current information and update the status report as needed. Should the species be Iisted by the U.S. Fish and Wildlife Service, the respective USFWS offices should maintain the information and distribute new findings to the interested parties.

\section{NEF INFORMATION}

21. Record of revisions: Not currently available. 


\section{Literature cited}

Bamberg, S.A. 1964. Ecology of the vegetation and soils associated with calcareous parent material in the alpine region of Montana. University of California, Davis. PhD. Thesis. 91 pp.

Bamberg, S.A. and J. Major. 1968. Ecology of the vegetation and soils associated with calcareous parent materials in three alpine regions of Montana. Ecol. Monogr. 42:417-450.

Barr, C.A. 1983. Jewels of the Plain. University of Minnesota Press, Minneapolis. $236 \mathrm{pp}$.

Caprio, J.M. and G.A. Nielsen. 1992. Climate atlas of Montana. Montana State University. Bozeman, MT. 63 pp.

Dorn, R.D. 1984. Vascular plants of Montana. Mountain West Publishing, Cheyenne, WY. 276 pp.

Fenneman, N.M. 1931. Physiography of western United states. MCGraw-Hill Book Company, New York. 534 pp.

Hitchcock, C.L., A. Cronquist, M. Ownbey, and J.W. Thompson. 1984. Vascular plants of the Pacific Northwest, Part Five. University of Washington Press, Seattle. $343 \mathrm{pp}$.

Lesica, P. and J.S. Shelly. 1991. Sensitive, threatened and endangered vascular plants of Montana. Montana Natural Heritage Program, Helena. $88 \mathrm{pp}$.

Mudge, M.R. and R.L. Earhart. 1977. Geologic map of the Bob Marshall and Great Bear Wildeernesses and adjacent study areas, Montana. U.S. Geological Survey, miscellaneous investigations series. Reston, VA.

Nesom, G.L. 1989. Intragenic taxonomy of new world Erigeron (Compositae: Astereae). Phytologia 67 (1):67-93.

Nesom, G.L. and W.A. Weber. 1983. A new wooly-headed, monocephalous Erigeron (Asteraceae) from Montana. Madrono $30: 2450249$.

Spongberg, S.A. 1971. A systematic and evolutionary study of North American arctic and alpine monocephalous species of Erigeron (Compositae). PhD Thesis, Univ. North Carolina, Chapel Hill.

U.S. Department of Interior, Fish and Wildlife Service. 1990. Endangered and threatened wildlife and plants: review of plant taxa for listing as endangered or threatened species. Federal Register 50 CFR Part 17: 6184-6229.

Visher, S.S. 1954. Climatic atlas of the United States. Harvard University Press, Cambridge, MA. $403 \mathrm{pp}$. 
APPENDIX A. Close-ups and habitat photos of Erigeron lackschewitzii 
Erigeron lackschewitzii close-up of typical plant having a single flowering stem

Note surface made up of Carex rupestris turf

Our Lake (\#007) 24 July 1992




Erigeron lackschewitzii close-up of two multi-stemmed plants, with optimal plant vigor

Note relative synchrony of flowering

steamboat Lookout (\#012) 28 July 1992




Erigeron lackschewitzii sympatric with $\underline{E}$. ochroleucus in an extremely varren site.

Note the hairy involcre and the ligules on $\underline{E}$. lackschewitzii as they project upward on this mature infloresence

Washboard Reef (\#009) 25 July 1992

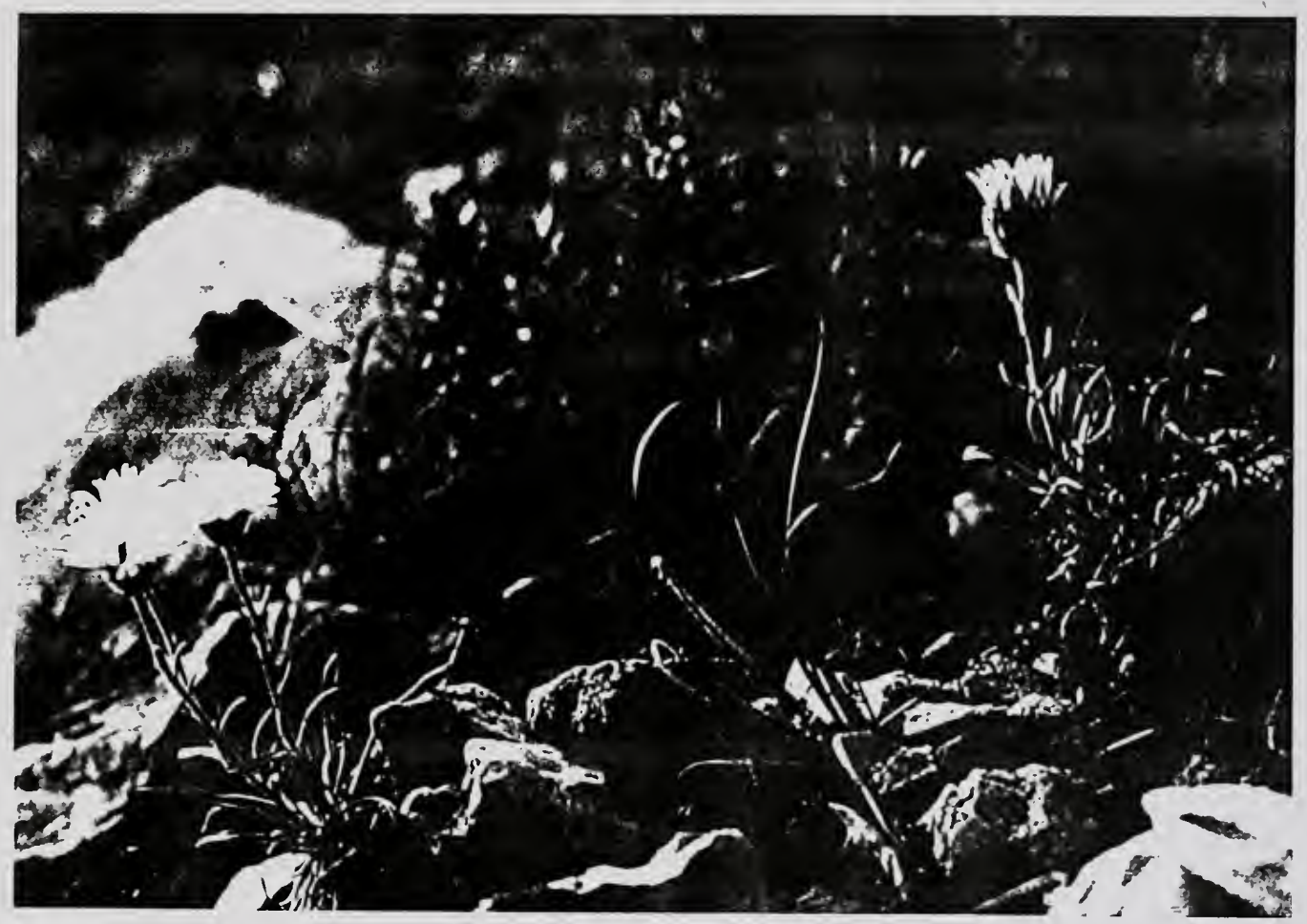


Erigeron lackschewitzii habitat at its driest extreme

Note ridge crest setting

Washboard Reef (\#009) 25 July 1992




Erigeron lackschewitzii typical habitat in terms of vegetation cover, aspect and slope

Note Cardamine rupicola habitat on opposite scree slope

Crown Mountain (\#006) 23 July 1992




Erigeron lackschewitzii habitat having relatively high mesic plant component

Note potentilla fruticosa, Castilleja pulchella

Steamboat Lookout (\#012) 28 July 1992

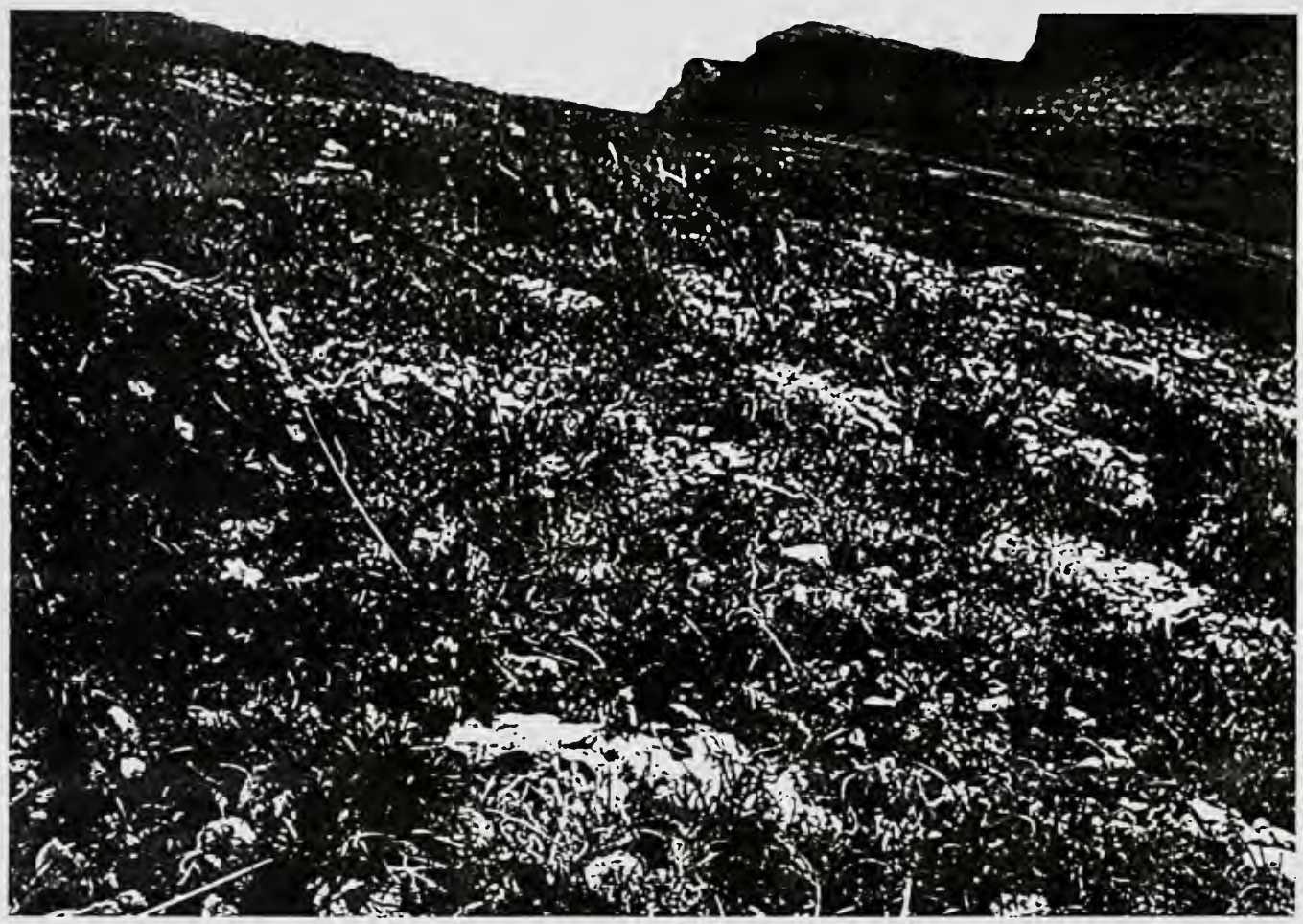


APPENDIX B. Element Occurrence Records 
February 16, 1993

MONTANA NATURAL HERITAGE PROGRAM

Element Occurrence Record

Scientific Name: ERIGERON LACKSCHEWITZII

Common Name: FRONT MOUNTAIN FLEABANE

Global rank: G2Q Forest service status:

state rank: $\quad$ 2 Federal status: C2

Element occurrence code: PDAST3M4F0.001

Element occurrence type:

Survey site name: MOUNT WRIGHT

EO rank: BC

EO rank comments: FAIR POPULATION SIZE.

County: TETON

USGS quadrangle: MOUNT WRIGHT

Township: Range: Section: TRS comments:

026N 010W 25 S2; 26 SE4

$\begin{array}{rll}\text { Survey date: } & 1982-07-23 & \text { Elevation: } 7500- \\ \text { First observation: } & 1982 & \text { Slope/aspect: } \\ \text { Last observation: } & 1992-07-17 & \text { Size (acres): }\end{array}$

Location:

EAST FLANK OF MOUNT WRIGHT, EAST FRONT RANGE; NORTH OF TRAIL IN SADDLE.

Element occurrence data:

1992: PEAK FLOWERING ON 17 JULY. 1983: SCATTERED PLANTS JUST ABOVE UPPER KRUMMHOLZ. 1982: MANY PLANTS, ABOUT 100, JUST BELOW DRY LIMESTONE HALL

General site description:

NARROW, STEEP LIMESTONE OUTCROP IN CAREX RUPESTRIS HABITAT TYPE BETWEEN CLUMPS OF DRYAS, WITH ERIGERON OCHROLEUCUS, POTENTILLA NIVEA, ANDROSACE CHAMAEJASME.

Land owner/manager:

BOB MARSHALL WILDERNESS

LEWIS \& CLARK NATIONAL FOREST, ROCKY MOUNTAIN RANGER DISTRICT

Comments:

RECENTLY DESCRIBED STATE ENDEMIC. COLLECTIONS MADE OF INDIVIDUAL FLOWER HEADS IN 1992 FOR MORPHOMETRIC STUDY.

Information source:

LACKSCHEWITZ, KLAUS. DIVISION OF BIOLOGICAL SCIENCES, UNIV. OF MONTANA, MISSOULA, MT 59812 .

Specimens:

LACKSCHEWITZ, K. (10085, 10506). 1982 \& 1983. SPECIMEN \#S 089924, 098541 . MONTU.

HEIDEL, B. (844). 1992 . 
February 16, 1993

MONTANA NATURAL HERITAGE PROGRAM

Element Occurrence Record

Scientific Name: ERIGERON LACKSCHEWITZII

Common Name: FRONT MOUNTAIN FLEABANE

Global rank: G2Q Forest Service status:

State rank: S2 Federal status: C2

Element occurrence code: PDAST3M4F0.002

Element occurrence type:

Survey site name: HEADQUARTERS CREEK PASS/ROCKY MOUNTAIN

EO rank: B

EO rank comments: SCATTERED SMALL TO MODERATE COLONIES, MOSTLY IN UNDISTURBED AREAS.

County: TETON

USGS quadrangle: OUR LAKE

Township: Range: Section: TRS comments:

024N $\quad$ NO9W E2; 30, NE4

Survey date: 1989-08-10 Elevation: 7760 -

First observation: 1978 Slope/aspect: LEVEL-35\%/WEST

Last observation: 1989-08-10 Size (acres): 10

Location:

ROCKY MOUNTAIN FRONT RANGE, HEADQUARTERS CREEK PASS AND WEST SLOPE OF ROCKY MOUNTAIN.

Element occurrence data:

CA. 200-300 PLANTS, IN THREE AREAS; MOST ABUNDANT ON THE SADDLE WEST OF THE SUMMIT OF ROCKY MOUNTAIN.

General site description:

DRY, TURFY MEADOWS, AND ON ROCK LEDGES, LIMESTONE PARENT MATERIAL;

WITH ERIGERON COMPOSITUS, ANTENNARIA AROMATICA, DRYAS OCTOPETALA, SEDUM ROSEUM.

Land owner/manager:

BOB MARSHALL WILDERNESS

LEWIS \& CLARK NATIONAL FOREST, ROCKY MOUNTAIN RANGER DISTRICT

Comments:

VOUCHERS-LACKSCHEWITZ, K.H. (8487), 1978, MONTU (81263); SHELLY, J.S. (1601) AND L.A. SCHASSBERGER, 1989, MONTU.

Information source:

SHELLY, J.S. 1989. FIELD SURVEYS IN TETON COUNTY OF 7-10, 21-23, AND 28-30 AUGUST.

Specimens: 
February 16, 1993

MONTANA NATURAL HERITAGE PROGRAM

Element Occurrence Record

Scientific Name: ERIGERON LACKSCHEWITZII

Common Name: FRONT MOUNTAIN FLEABANE

Global rank: G2Q Forest service status:

State rank: 52 Federal status: C2

Element occurrence code: PDAST3M4F0.003

Element occurrence type:

Survey site name: SOCK LAKE

EO rank:

EO rank comments:

county: LEWIS AND CLARK FLATHEAD

USGS quadrangle: THREE SISTERS

Township: Range: Section: TRS comments:

024N O1IW 31 NE4

Survey date: 1979-07-26 Elevation: 8200 -

First observation: 1979 Slope/aspect:

Last observation: 1979-07-26 Size (acres): 2

Location:

FLATHEAD RANGE, "N WALL" OF CONTINENTAL DIVIDE, SUMMIT OF MOUNTAIN ABOVE SOCK LAKE.

Element occurrence data:

LARGEST POPULATION KNOWN, CA. 500 PLANTS; ON BOUNDARY OF WATERSHED 17010209; ALSO ON BOUNDARY OF FLATHEAD NATIONAL FOREST.

General site description:

COMMON IN ARCTOSTAPHYLOS POLYGONS, ALSO IN DRY MEADOW, ASSOCIATED WITH ERIGERON RADICATUS AND TOWNSENDIA PARRYI.

Land owner/manager:

LEWIS \& CLARK NATIONAL FOREST, ROCKY MOUNTAIN RANGER DISTRICT

SUN RIVER WILDLIFE MANAGEMENT AREA

BOB MARSHALL WILDERNESS

Comments:

TYPE LOCALITY, RECENTLY DESCRIBED STATE ENDEMIC; VOUCHER -

LACKSCHEWITZ (9101), 1979, MONTU (HOLOTYPE), COLO (ISOTYPE).

Information source:

NESOM, G.L., AND W.A. WEBER. 1983. A NEW WOOLY-HEADED, MONOCEPHALOUS

ERIGERON (ASTERACEAE) FROM MONTANA. MADRONO 30:245-249

Specimens : 
February 16,1993

MONTANA NATURAL HERITAGE PROGRAM

Element Occurrence Record

Scientific Name: ERIGERON LACKSCHEWITZII

Common Name: FRONT MOUNTAIN FLEABANE

Global rank: G2Q Forest service status:

State rank: $\mathrm{S2}$ Federal status:

C2

Element occurrence code: PDAST3M4F0.004

Element occurrence type:

Survey site name: CORRUGATE RIDGE

Eo rank:

EO rank comments:

county: TETON

FLATHEAD

USGS quadrangle: GATEWAY PASS

Township: Range: Section: TRS comments:

026N 010W $16 \quad 9$

$\begin{array}{rll}\text { Survey date: } & 1983-07-29 & \text { Elevation: } 8000 \\ \text { First observation: } & 1983 & \text { Slope/aspect: } \\ \text { Last observation: } & 1983-07-29 & \text { Size (acres): } 10\end{array}$

Location:

CORRUGATE RIDGE, ALONG CONTINENTAL DIVIDE ABOVE W. SIDE OF HEADWATERS OF BRUCE CREEK.

Element occurrence data:

SEVERAL SMALL COLONIES, FEWER THAN 200 PLANTS.

General site description:

BOULDER FIELD WITH A FEW SMALL LEVEL PLATEAUS; WITH ANDROSACE LEHMANNIANA AND ANTENNARIA MONOCEPHALA.

Land owner/manager:

FLATHEAD NATIONAL FOREST, SPOTTED BEAR RANGER DISTRICT

BOB MARSHALI WILDERNESS

LEWIS \& CLARK NATIONAL FOREST, ROCKY MOUNTAIN RANGER DISTRICT

Comments:

RECENTLY DESCRIBED STATE ENDEMIC.

Information source:

LACKSHEWITZ, KLAUS. DIVISION OF BIOLOGICAL SCIENCES, UNIVERSITY OF

MONTANA, MISSOULA, MT 59812 .

Specimens: 
March 29, 1993

MONTANA NATURAL HERITAGE PROGRAM

Element Occurrence Record

Scientific Name: ERIGERON LACKSCHEWITZII

Common Name: FRONT MOUNTAIN FLEABANE

Global rank: G2Q Forest Service status:

state rank: S2 Federal status: C2

Element occurrence code: PDAST3M4F0.005

Element occurrence type:

Survey site name: MOUNT PATRICK GASS EO rank:

EO rank comments:

county: TETON

USGS quadrangle: GATEWAY PASS

WALLING REEF

Township: Range: Section: TRS comments:

026N 010W $10 \quad$ N2; 15 NE4

Survey date:

First observation:

Last observation:
1983

1992-08-01
Elevation: $7800-7840$

Slope/aspect: 40-45\%/ NORTH Size (acres): 20

Location:

SOUTH FLANKS OF MOUNT PATRICK GASS, ON DIVIDE BETWEEN BRUCE CREEK AND CRAZY CREEK, AND ON NORTH FLANK OF NW-SE RIDGE SOUTH OF MOUNT PATRICK GASS.

Element occurrence data:

1992: 30-40 PLANTS LOCATED IN THIRD (WESTERNMOST) SUBPOPULATION. 1983: SCATTERED SINGLE PLANTS, LESS THAN 100; TWO SUBPOPULATIONS.

General site description:

LIMESTONE PARENT MATERIAL, WINDY EXPOSED SLOPES. WITH ERIGERON

SIMPLEX, POA ALPINA, FESTUCA RUBRA. ERIGERON COMPOSITUS IN WESTERNMOST SUBPOPULATION.

Land owner/manager:

BOB MARSHALL WILDERNESS

LEWIS \& CLARK NATIONAL FOREST, ROCKY MOUNTAIN RANGER DISTRICT

Comments:

RECENTLY DESCRIBED STATE ENDEMIC. THIRD SUBPOPULATION LOCATED BY T. KERSTETTER, MSU, IN 1992.

Information source:

LACKSHEWITZ, KLAUS. DIVISION OF BIOLOGICAL SCIENCES, UNIVERSITY OF MONTANA, MISSOULA, MT 59812 .

Specimens:

LACKSHEWITZ, K. (10618) . 1983. SPECIMEN \#098536. MONTU.

KERSTETTER, T. (S.N.). 1992. MONT. 
February 16,1993

MONTANA NATURAL HERITAGE PROGRAM

Element Occurrence Record

Scientific Name: ERIGERON LACKSCHEWITZII

Common Name: FRONT MOUNTAIN FLEABANE

Global rank: G2Q Forest Service status:

State rank: 52 Federal status: C2

Element occurrence code: PDAST3M4F0.006

Element occurrence type:

Survey site name: CROWN MOUNTAIN

EO rank: $B$

EO rank comments: GOOD-SIZED POPULATION.

County: LEWIS AND CLARK

USGS quadrangle: SCAPEGOAT MOUNTAIN

Township: Range: Section: TRS comments:

019N OO9W 28 NW4, 29 NE4

$\begin{array}{rll}\text { Survey date: } & 1992-07-23 & \text { Elevation: } 7200-7700 \\ \text { First observation: } & 1986 & \text { Slope/aspect: } \\ \text { Last observation: } & 1992-07-23 & \text { Size (acres): } 10\end{array}$

Location:

FRONT RANGE MOUNTAINS, SOUTH-FACING SLOPES OF CROWN MOUNTAIN WEST OF

THE PASS, ACROSS FROM PACK TRAIL.

Element occurrence data:

1992: 150-300 PLANTS, IN EARLY FRUIT ON 23 JULY. 1986: RARE.

General site description:

IN LIMESTONE TALUS ON SOUTH-FACING SLOPES. OCCASIONAL BETWEEN MATS OF

DRYAS OCTOPETALA AND ARCTOSTAPHYLOS UVA-URSI IN AREAS DOMINATED BY

CAREX RUPESTRIS. ASSOCIATED SPECIES: POTENTILLA FRUTICOSA, BUPLEURUM AMERICANUM, ANDROSACE CHAMAEJASME.

Land owner/manager:

SCAPEGOAT WILDERNESS

LEWIS \& CLARK NATIONAL FOREST, ROCKY MOUNTAIN RANGER DISTRICT

Comments:

SYMPATRIC WITH E. SIMPLEX ON MIDSLOPE RIDGE.

Information source:

HEIDEL, B. 1992. FIELD SURVEY TO CROWN MOUNTAIN OF 23 JULY.

Specimens:

LESICA, P. (4044). 1986. SPECIMEN \#104490. MONTU.

HEIDEL, B. $(856)$. 1992. MONT. 
February 16, 1993

MONTANA NATURAL HERITAGE PROGRAM

Element Occurrence Record

Scientific Name: ERIGERON LACKSCHEWITZII

Common Name: FRONT MOUNTAIN FLEABANE

Global rank: G2Q Forest service status:

state rank: $\mathrm{S} 2$

Federal status: $\quad$ 2

Element occurrence code: PDAST3M4F0.007

Element occurrence type:

Survey site name: OUR IAKE

EO rank: AB

EO rank comments:

County: TETON

USGS quadrangle: OUR IAKE

Township: Range: Section: TRS comments:

024N 009W 18 W2.

Survey date: 1989-08-09 Elevation: 8400 -

First observation: 1986 Slope/aspect: 5-25\% / EAST, WEST

Last observation: 1992-07-24 Size (acres): 5

Location:

FRONT RANGE MOUNTAINS, CA. 25 MILES WEST OF CHOTEAU, ABOVE OUR LAKE ON RIDGE NORTH OF HEADQUARTERS PASS AND ON SADDLE SLOPES WEST OF OUR LAKE.

Element occurrence data:

1992: 200-400 PLANTS, MOST DENSELY CONCENTRATED ON WEST-FACING SLOPE.

IN PEAK FLOWERING ON 24 JULY, AN EARLY YEAR. 1989: COMMON; LARGE POPULATION (ROE). CA. 25 PLANTS OVER A ONE ACRE AREA, IN FLOWER (PHILIIPS, FIELD).

General site description:

IN ALPINE TURF; WITH DRYAS OCTOPETALA, CAREX RUPESTRIS, KOBRESIA MYOSUROIDES, ERIGERON COMPOSITUS, AND ASTRAGALUS MOLYBDENUS. ALPINE FELLFIELD; LIMESTONE BEDROCK.

Land owner/manager:

BOB MARSHALL WILDERNESS

LEWIS \& CLARK NATIONAL FOREST, ROCKY MOUNTAIN RANGER DISTRICT

Comments:

SITE REVISITED BY B. HEIDEL (MTNHP) IN 1992. WITHIN I MILE AND POSSIBLY A SUBPOPULATION OF OCCURRENCE \#002 (HEADQUARTERS CREEK PASS). 1992 COLLECTIONS MADE FOR GENETICS RESEARCH.

Information source:

PHILLIPS, W. AND D. FIELD. LEWIS AND CLARK NATIONAL FOREST, P.O. BOX

871, GREAT FALLS, MT 59403.

Specimens : 
Scientific Name: ERIGERON LACKSCHEWITZII

Common Name: FRONT MOUNTAIN FLEABANE

Global rank: $\mathrm{G} 2 \mathrm{Q}$

Forest Service status:

state rank: $\mathrm{S2}$

Federal status: C2

Element occurrence code: PDAST3M4F0.008

Element occurrence type:

Survey site name: TETON SKI AREA PEAK

EO rank: C

EO rank comments:

County: TETON

USGS quadrangle: MOUNT WRIGHT

Township: Range: Section: TRS comments:

$025 \mathrm{~N}$

OIOW 12 SE4

Survey date: 1989-08-08 Elevation: 7960 -

First observation: 1989 . Slope/aspect: 3 o / NW

Last observation: 1989-08-08 Size (acres): 1

Location:

CA. 34 MILES WEST OF CHOTEAU, ON WEST SIDE OF PEAK ABOVE TETON PASS SKI AREA.

Element occurrence data:

SMALL POPULATION.

General site description:

IN MOIST, TURFY, LIMESTONE SOIL, WITH DRYAS OCTOPETALA, SMELOWSKIA

CALYCINIA, ASTRAGALUS MOLYBDENUS, AND ANDROSACE CHAMAEJASME.

Land owner/manager:

LEWIS \& CLARK NATIONAL FOREST, ROCKY MOUNTAIN RANGER DISTRICT

Comments :

VOUCHER - SCHASSBERGER, L.A. (339), WITH J. PIERCE, 1989, MONTU.

Information source:

SCHASSBERGER, L.A. 1989. FIELD SURVEYS OF THE FRONT RANGE MOUNTAINS, 7-10 AND 2I-23 AUGUST.

Specimens: 
February 16, 1993

MONTANA NATURAL HERITAGE PROGRAM

Element Occurrence Record

Scientific Name: ERIGERON LACKSCHEWITZII

Common Name: FRONT MOUNTAIN FLEABANE

Global rank: G2Q Forest Service status:

State rank: S2 Federal status: C2

Element occurrence code: PDAST3M4F0.009

Element occurrence type:

Survey site name: WASHBOARD REEF

EO rank: $C D$

EO rank comments: SMALL POPULATION, MARGINAL hABITAT.

County: TETON

USGS quadrangle: PORPHYRY REEF

Township: Range: Section: TRS comments:

025N 010W 10 NW4SW4

Survey date: 1992-07-25 Elevation: 7920 -

First observation: 1992-07-25 Slope/aspect: 30\%/SOUTHWEST

Last observation: 1992-07-25 Size (acres):

Location:

NORTH OF TRAIL 117 ON WASHBOARD REEF RIDGELINE; OVER 6 MILES FROM WEST FORK TETON TRAILHEAD.

Element occurrence data:

DIFFUSE POPULATION OF 8 PLANTS ON 0.5 MILE OF RIDGE, LOW VIGOR, IN LATE FLOWER.

General site description:

LIMESTONE PARENT MATERIAL ON FLAT BARREN SLOPE FACING SOUTHWEST. EXTREMELY SPARSELY VEGETATED. ASSOCIATED SPECIES: CAREX RUPESTRIS, ANDROSACE CHAMAEJASME, SMELOWSKIA CALYCINA, SENECIO CANA, ERIGERON OCHROLEUCUS, ERIGERON COMPOSITUS.

Land owner/manager:

BOB MARSHALL WILDERNESS

LEWIS \& CLARK NATIONAL FOREST, ROCKY MOUNTAIN RANGER DISTRICT

Comments :

Information source:

HEIDEL, B. 1992. [FIELD SURVEY TO WASHBOARD REEF OF 25 JULY.]

Specimens: 
February 16,1993

MONTANA NATURAL HERITAGE PROGRAM

Element Occurrence Record

Scientific Name: ERIGERON LACKSCHEWITZII

Common Name: FRONT MOUNTAIN FLEABANE

Global rank: G2Q Forest service status:

state rank: $\mathrm{S2}$

Federal status: $\mathrm{C2}$

Element occurrence code: PDAST3M4F0.010

Element occurrence type:

Survey site name: SWIFT RIVER

EO rank: $C D$

EO rảnk comments: SMALL OUTLIER POPULATION, MARGINAL HABITAT.

county: PONDERA

USGS quadrangle: FISH LAKE

Township: Range: Section: TRS comments:

$028 \mathrm{~N} 010 \mathrm{~W} \quad 35$ N2NE4

Survey date: 1992-07-26 Elevation: 6400 -

First observation: 1992-07-26 Slope/aspect:

Last observation: 1992-07-27 size (acres): 1

Location:

ABOVE SWIFT RIVER RESERVOIR, 1.25 MILES SOUTHEAST OF DAM ON RIDGE AT EAST EDGE OF FRONT RANGE.

Element occurrence data:

5 PLANTS, MULTI-STEMMED AND VIGOROUS, IN LATE FLOWER.

General site description:

TOP OF A DRAW ABOVE SWIFT RESERVOIR, ON STEEP PARTIALLY FORESTED

KRUMMHOLTZ SLOPE. ASSOCIATED SPECIES: PINUS FLEXILIS, ARCTOSTAPHYLOS

UVA-URSI, GRASSES, SHEPERDIA ARGENTEA, ANDROSACE CHAMAEJASME, HEDYSARUM SULPHURESCENS, ZIGADENUS ELEGANS, POTENTILLA FRUTICOSA.

Land owner/manager:

STATE LAND - UNDESIGNATED

Comments :

EXTENSIVE DIEBACK OF PINUS FLEXILIS ON THE SLOPE; SOME OR ALL DUE TO

FIRE. WELL-WORN GAME TRAILS CROSS THE SLOPE. COLLECTION MADE

PREMATURELY BEFORE POPULATION COUNT.

Information source:

HEIDEL, B. 1992. [FIELD SURVEY TO SWIFT RIVER RESERVIOR OF 26 JULY.]

Specimens:

HEIDEL, B. L. (873). 1992. MONT. 
February 16,1993

MONTANA NATURAL HERITAGE PROGRAM

Element Occurrence Record

Scientific Name: ERIGERON LACKSCHEWITZII

Common Name: FRONT MOUNTAIN FLEABANE

Global rank: G2Q Forest Service status:

State rank: $\quad$ 2 Federal Status: C2

Element occurrence code: PDAST3M4F0.011

Element occurrence type:

Survey site name: VOLCANO REEF

EO rank: CD

EO rank comments: SMALL OUTLIER POPULATION; MARGINAL HABITAT.

county: TETON

USGS quadrangle: VOLCANO REEF

Township: Range: Section: TRS comments:

026N $009 W \quad 11$ NE4SE4; SEC 12 SW4SW4

$\begin{array}{rll}\text { Survey date: } & 1992-07-27 & \text { Elevation: } 6740- \\ \text { First observation: } & 1992-07-27 & \text { Slope/aspect: } 20 \% / N N W \\ \text { Last observation: } & 1992-07-27 & \text { Size (acres): }\end{array}$

Location:

VOLCANO REEF RIDGETOP AT EAST EDGE OF FRONT RANGE, NORTH OF BLACKLEAF CANYON.

Element occurrence data:

10 PLANTS ACROSS 1.5 MILES OF RIDGE, INCLUDING ONE AGGREGATE OF 7 PLANTS. IN LATE FLOWER.

General site description:

Land owner/manager:

LEWIS \& CLARK NATIONAL FOREST, ROCKY MOUNTAIN RANGER DISTRICT

Comments :

Information source:

HEIDEL, B. L. 1992. [FIELD SURVEY TO VOLCANO REEF OF 27 JULY.]

Specimens: 
February 16,1993

MONTANA NATURAL HERITAGE PROGRAM

Element Occurrence Record

Scientific Name: ERIGERON LACKSCHEWITZII

Common Name: FRONT MOUNTAIN FLEABANE

Global rank: $G 2 Q$ Forest Service status:

state rank: $\quad S 2$

Federal status:

$\mathrm{C} 2$

Element occurrence code: PDAST3M4F0.012

Element occurrence type:

Survey site name: STEAMBOAT LOOKOUT

EO rank: B

EO rank comments: RELATIVELY LARGE POPULATION AND HIGH DENSITY.

County: LEWIS AND CLARK

USGS quadrangle: JAKIE CREEK

Township: Range: Section: TRS comments:

$018 \mathrm{~N} \quad 008 \mathrm{~W} \quad 17 \quad$ S2

Survey date: 1992-07-28 Elevation: $8280-8320$

First observation: 1992-07-28 Slope/aspect: $158 / \mathrm{SSW}$

Last observation: 1992-07-28 Size (acres): 5

Location:

LOWER EAST END OF RIDGE DIRECTLY NORTH OF STEAMBOAT MOUNTAIN LOOKOUT, NORTH OF UNNUMBERED TRAIL TO LOOKOUT; OVER 6 MILES ABOVE TRAILHEAD ON ELK CREEK.

Element occurrence data:

CA. 150 PLANTS, VIGOROUS CONDITION. ALTHOUGH MOST PLANTS WERE IN LATE FLOWER, MANY HAD MULTI-STEMMED CLUMP AT DIFFERENT STAGES, INCLUDING EARLY BUD.

General site description:

ALPINE LIMESTONE COBBLE SLOPE WITH CAREX RUPESTRIS PATTERNED TURF PATCHES AND WIDELY SPACED POTENTILLA FRUTICOSA. SEMI-SHELTERED SADDLE SETTING. ASSOCIATED SPECIES: SEDUM ROSEUM, OXYTROPIS SERICEA, CASTILLEJA PULCHELLA, ANDROSACE CHAMAEJASME, POA ALPINA, POLYGONUM VIVIPARUM, ZIGADENUS ELEGANS, CARDAMINE RUPICOLA.

Land owner/manager:

LEWIS \& CLARK NATIONAL FOREST, ROCKY MOUNTAIN RANGER DISTRICT SCAPEGOAT WILDERNESS

Comments:

REPEATER TOWER INSTALLATION PROPOSED AT LOOKOUT; LITTLE OR NO

POTENTIAL IMPACT. CARDAMINE RUPICOLA IS RARE IN ERIGERON

LACKSCHEWITZII HABITAT.

Information source:

HEIDEL, B. 1992. [MTNHP FIELD.SURVEY TO STEAMBOAT LOOKOUT OF 28 JULY.]

Specimens :

HEIDEL, B. (885). 1992. MONT. MONTU. 
APPENDIX C. Site Maps 

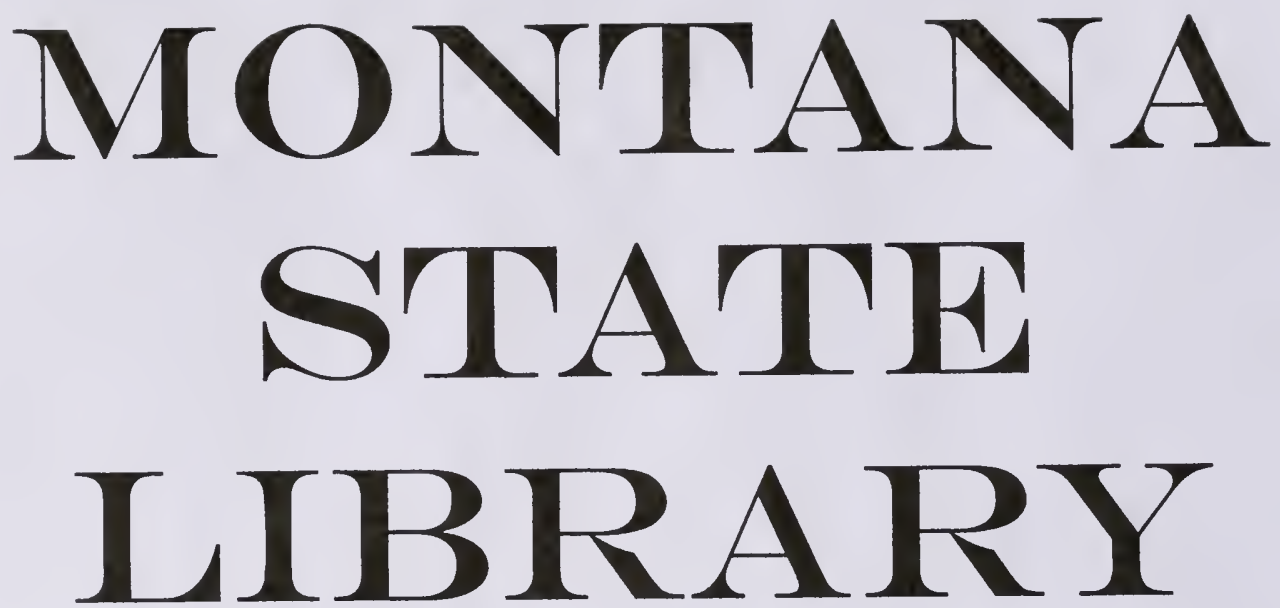